\title{
Screening and Selection of Media Components for Protease Production by Bacillus sp. EBTA6 Using Plackett-Burman Design
}

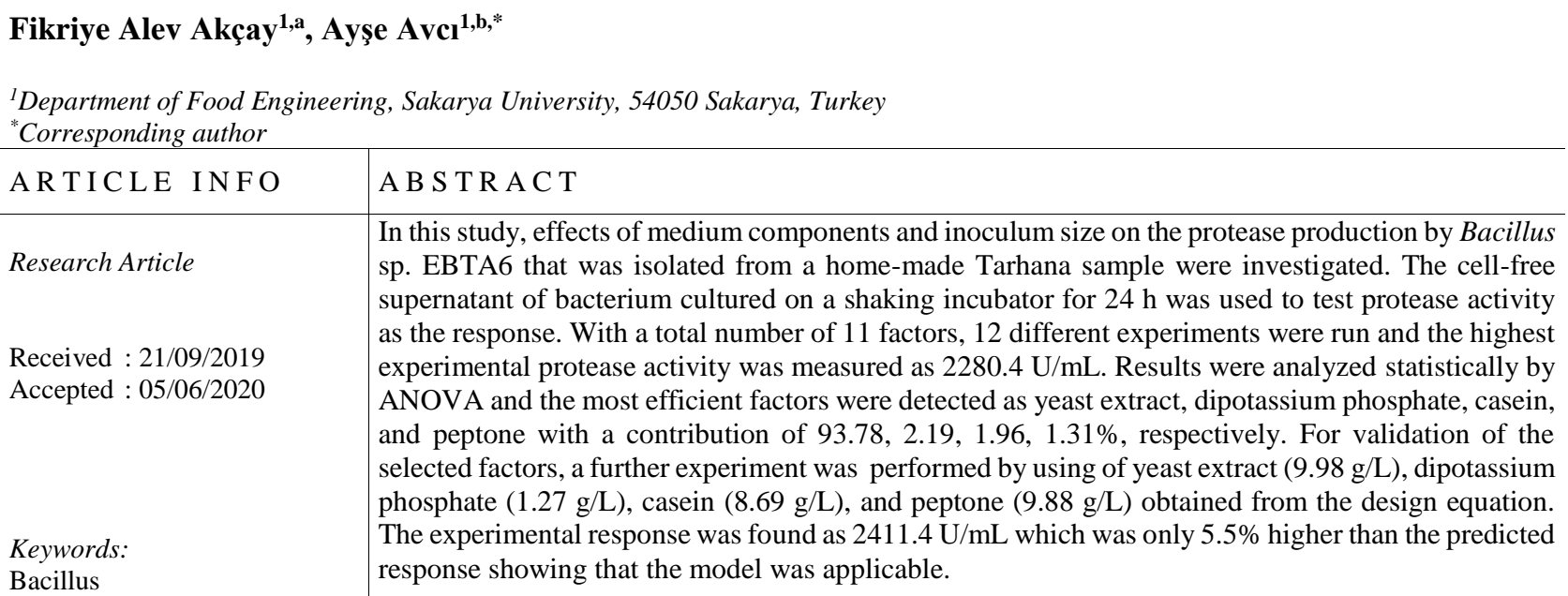

Plackett-Burman Design

Protease

Enzyme activity

Yeast extract

Türk Tarım - Gıda Bilim ve Teknoloji Dergisi, 8(6): 1250-1255, 2020

\section{Bacillus sp. EBTA6 ile Proteaz Üretimi için Plackett-Burman Dizaynı Kullanılarak Besiyeri Bileşenlerinin Taranması ve Seçimi}

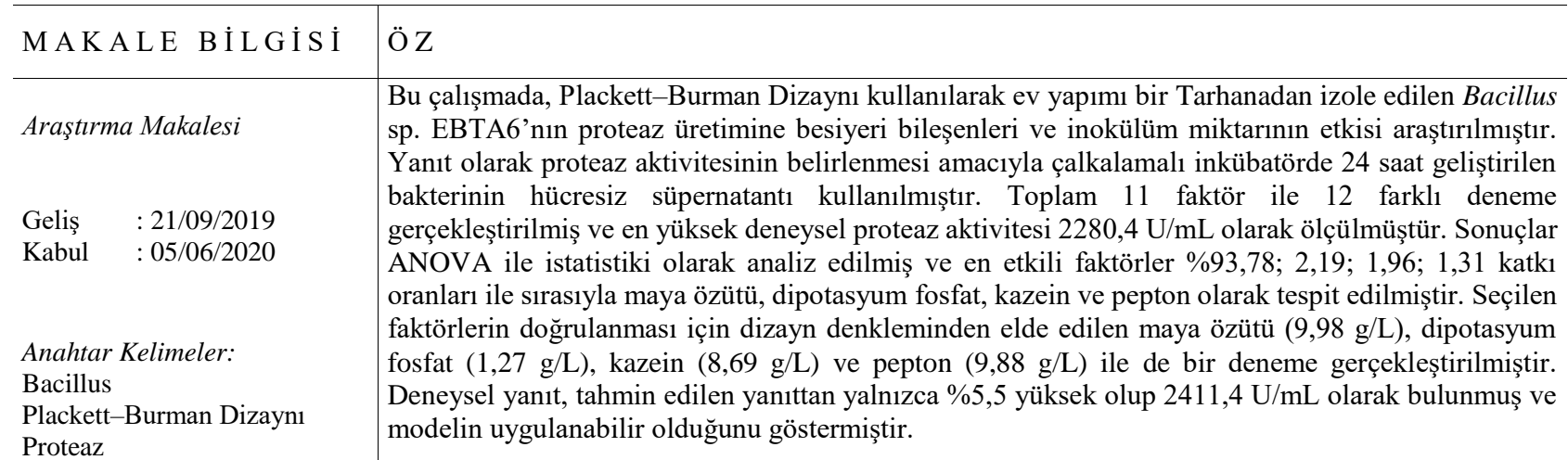

Proteaz

Enzim aktivitesi

Maya özütü 


\section{Introduction}

An increasing demand for enzyme industries encourages the researchers to seek for more efficient and cheaper sources (Kaur et al., 2017). Approximately $60 \%$ of the total enzyme demand of the global industrial market is supplied by proteases (Patil et al., 2018). Proteases (EC 3.4.21; also called as a proteinase or peptidase) catalyze the breakdown of peptide bonds in proteins resulting in smaller fragments i.e. peptides and/or amino acids (Rao et al., 1998). They are widely used in many industries such as detergent, food, pharmaceutical, textile, and chemistry for the purposes of leather and silk production, peptide synthesis, soy-processing, meat tenderization, silver recovery from waste X-ray films etc. (Horikoshi, 1999; Tari et al., 2006; Si et al., 2018; Limkar et al., 2019).

Since proteases are physiologically necessary for living organisms, they are being found in a wide diversity of sources including plants, animals, and microorganisms (Rao et al., 1998). Microorganisms are tremendous protease production factories owing to their diversity in nature and rapid growth (Rao et al., 1998; Si et al., 2018). In addition, they require less space for the cultivation, and can be manipulated genetically to render desired attributes. Thus, microbial proteases have appropriate characteristics for being used in the biotechnological applications (Rao et al., 1998; Gupta et al., 2002). Recent studies have demonstrated that proteases have been produced by yeast, molds and bacteria including Sporobolomyces roseus (Białkowska et al., 2018), Aspergillus sojae (Lim et al., 2019), Aeromonas hydrophila (Borhani et al., 2018) and Brevibacterium luteolum (Rao et al., 2017). Majority of the industrial proteases are obtained from the species of the genus Bacillus (Rekik et al., 2019). Various strains have been reported as protease producers including Bacillus firmus (Moon and Parulekar, 1991), Bacillus subtilis (Kembhavi et al., 1993), Bacillus licheniformis (Ferrero et al., 1996), Bacillus horikoshii (Joo et al., 2002), Bacillus mojavensis (Beg et al., 2003), Bacillus cereus (Banik and Prakash, 2004).

Fermentation parameters such as $\mathrm{pH}$, temperature, and inoculum size have a great effect on the protease production by microorganisms. Among media components, carbon and nitrogen sources are quite effective (Puri et al., 2002) and have to be optimized for each microorganism under study. Using statistical models to determine the effects of growth parameters on enzyme production has become substantially widespread. Therefore, the aim of this study is to determine the effect of inoculum size and media components including carbon and nitrogen sources as well as some minerals for protease production by Bacillus sp. EBTA6 using PlackettBurman Design.

\section{Materials and Methods}

\section{Materials}

Glucose, fructose, starch, yeast extract, peptone from meat, ammonium sulfate, magnesium sulfate heptahydrate, dipotassium phosphate, L-tyrosine, tris-(hydroxymethyl)aminomethane, nutrient agar and nutrient broth were purchased from Merck (Darmstadt, Germany). Casein and hydrochloric acid were purchased from Sigma-Aldrich (Steinheim, Germany). Sucrose was purchased from BDH Laboratory Supplies (Poole, England). All chemicals used were of analytical grade.

\section{Microorganism and Cultural Conditions}

The EBTA6 strain was previously isolated from a home-made tarhana sample and identified as a member of the genus Bacillus based on morphological, biochemical and phylogenetic analysis. It was stored in nutrient broth containing $50 \%$ glycerol at $-65^{\circ} \mathrm{C}$. The seed culture was prepared prepared by activating the strain on a nutrient agar plate followed by the incubation in nutrient broth at $33^{\circ} \mathrm{C}$ for $24 \mathrm{~h}$ on a shaking incubator (Benchmark, Incu-Shaker Mini) at $120 \mathrm{rpm}$.

\section{Methods}

\section{Plackett-Burman Design}

The Plackett-Burman is an experimental design to study the effects of various parameters on a certain production which prevents unnecessary repetitions using a limited number of experiments. The design allows to study in two factorial (i.e. -1 and +1 ) for " $n$ " variables in " $n+1$ " experiments (Karlapudi et al., 2018).

In this study, Plackett-Burman Design was used to screen the effect of eleven different variables (inoculum size and medium components) on the protease production by Bacillus sp. EBTA6. The variables and their levels are given in Table 1. The statistical software package Design Expert (v.11, Stat-Ease Inc., Minneapolis, USA) was used to conduct the analysis by applying twelve experiments given by the model (Table 2). Experiments were performed in $100 \mathrm{~mL}$ Erlenmeyer flasks containing $30 \mathrm{~mL}$ media and incubations were carried out at $33^{\circ} \mathrm{C}$ for $24 \mathrm{~h}$ on a shaking incubator held at $120 \mathrm{rpm}$. Then the samples were analyzed for protease activities.

All experiments were conducted in duplicate and the average of the two responses obtained from each experiment was taken as the result. The effect of each factor on enzyme activity was calculated according to following equation (Eq. 1):

$$
\mathrm{E}_{\mathrm{i}}=\frac{\sum \mathrm{p}_{\mathrm{i}+}-\sum \mathrm{p}_{\mathrm{i}-}}{\mathrm{N}}
$$

$\mathrm{E}_{\mathrm{i}}$ is the effect of factor $\mathrm{i}$ under study; $\mathrm{P}_{\mathrm{i}+}$ and $\mathrm{P}_{\mathrm{i}}$ are the responses (protease activity) of the experiment when the factor $i$ was at its high (+1) and low (-1) level, respectively, and $\mathrm{N}$ is the total number of experiments. Analysis of variance (ANOVA) was applied to determine the significance of the model. A half-normal plot and Pareto chart were used to detect the influence of the parameters on yield.

\section{Protease Activity}

Protease activity was determined by using casein as substrate with its $1 \%$ solution in Tris- $\mathrm{HCl}$ buffer, $\mathrm{pH} 8$. The enzyme samples were centrifuged at $9000 \mathrm{rpm}$ for $5 \mathrm{~min}$ (Hettich Universal, $320 \mathrm{R}$ ), and then $0.5 \mathrm{~mL}$ of supernatant was mixed with $1 \mathrm{~mL}$ of casein solution. The mixture was incubated on a shaking water bath (Wisd, WSB-30) at $60^{\circ} \mathrm{C}$ for 15 minutes and the reaction was ceased by the addition of $2 \mathrm{~mL}$ trichloroacetic acid (10\%). Subsequently, the mixture was treated by a centrifuge at $9000 \mathrm{rpm}$ for 5 minutes to precipitate the proteins and the absorbance values of resulting supernatant was measured at $280 \mathrm{~nm}$ by using UV-VIS spectrophotometer (Shimadzu, UVmini-1240). To determine the absorbance values acquired from medium, 
$0.5 \mathrm{~mL}$ distilled water was used in place of enzyme solution as blank solution and the experiment was achieved under the same conditions. Enzyme activity was calculated by using the standard curve prepared with tyrosine. One unit of protease activity was defined as the amount of the enzyme that liberates $1 \mu \mathrm{mol}$ tyrosine in 1 minute under the reaction conditions (Eq. 2).

$$
\begin{aligned}
& \mathrm{EA}=\frac{\mathrm{X}(\mu \mathrm{mol}) \times \mathrm{TV}(\mathrm{mL})}{\mathrm{AOE}(\mathrm{mL}) \times \mathrm{IT}(\text { minutes })} \times \mathrm{DF} \\
& \mathrm{EA}: \text { Enzyme activity } \\
& \mathrm{X}: \text { Tyrosine curve factor } \\
& \mathrm{TV}: \text { Total volume }(\mathrm{mL}) \\
& \mathrm{AOE}: \text { Amount of enzyme }(\mathrm{mL}) \\
& \mathrm{IT} \quad: \text { Incubation time (minutes) } \\
& \mathrm{DF} \quad: \text { Dilution factor }
\end{aligned}
$$

Table 1. Different variables and their levels

\begin{tabular}{c|lcccc}
\hline RN & \multicolumn{1}{c}{ Variable Name } & Variable Code & -1 (Min. Level) & +1 (Max. Level) & Unit \\
\hline 1 & Inoculum size & $\mathrm{In}$ & 1 & 10 & $\%$ \\
2 & Glucose & $\mathrm{Gl}$ & 5 & 20 \\
3 & Sucrose & $\mathrm{Su}$ & 5 & 20 \\
4 & Fructose & $\mathrm{Fr}$ & 5 & 20 \\
5 & Starch & $\mathrm{St}$ & 5 & 20 \\
6 & Yeast extract & $\mathrm{Ye}$ & 1 & 10 & $\mathrm{~g}$ \\
7 & Casein & $\mathrm{Ca}$ & 10 & 10 \\
8 & Peptone & $\mathrm{Pe}$ & 1 & 10 \\
9 & Ammonium sulphate & $\mathrm{Am}$ & 1 & 2 \\
10 & Magnesium sulphate & $\mathrm{Ma}$ & 0.1 & 2 \\
11 & Dipotassium phosphate & $\mathrm{Di}$ & 0.1 & \\
\hline
\end{tabular}

\section{Validation}

For validation of the chosen model, an experiment was actualized according to the equation (Eq. 3) given by the software which was illustrated in the Results and Discussion Section. The equation in terms of optimum predicted factors was used to make validation about response (enzyme activity) for the high and low levels of each factor. The levels were specified in the original units for each factor. This equation was not used to determine the relative impact of each factor because the coefficients were scaled to accommodate the units of each factor. The actual response was measured and compared with the predicted value. Each experiment was conducted in duplicates and the average data was presented.

RN: Run No

Table 2. The Plackett-Burman experimental design matrix with protease production

\begin{tabular}{c|ccccccccccccccc}
\hline RN & In & Gl & Su & Fr & St & Ye & Ca & Pe & Am & Ma & Di & EPA & PPA & Error \\
\hline 1 & 1 & 5 & 5 & 5 & 5 & 1 & 1 & 1 & 1 & 0.1 & 0.1 & 41.5 & 31.1 & 10.4 \\
2 & 10 & 5 & 5 & 5 & 20 & 1 & 10 & 10 & 1 & 2 & 2 & 726.4 & 736.2 & -9.8 \\
3 & 10 & 20 & 20 & 5 & 5 & 1 & 10 & 1 & 10 & 2 & 0.1 & 277.2 & 287.1 & -9.9 \\
4 & 1 & 20 & 20 & 20 & 5 & 1 & 1 & 10 & 1 & 2 & 2 & 517.5 & 527.4 & -9.9 \\
5 & 10 & 20 & 5 & 20 & 20 & 10 & 1 & 1 & 1 & 2 & 0.1 & 1681.9 & 1691.7 & -9.8 \\
6 & 10 & 20 & 5 & 5 & 5 & 10 & 1 & 10 & 10 & 0.1 & 2 & 2093.7 & 2083.8 & 9.9 \\
7 & 10 & 5 & 20 & 20 & 5 & 10 & 10 & 10 & 1 & 0.1 & 0.1 & 2187 & 2177.2 & 9.8 \\
8 & 1 & 5 & 5 & 20 & 5 & 10 & 10 & 1 & 10 & 2 & 2 & 2280.4 & 2290.2 & -9.8 \\
9 & 10 & 5 & 20 & 20 & 20 & 1 & 1 & 1 & 10 & 0.1 & 2 & 496.5 & 486.7 & 9.8 \\
10 & 1 & 20 & 20 & 5 & 20 & 10 & 10 & 1 & 1 & 0.1 & 2 & 2223.2 & 2213.3 & 9.9 \\
11 & 1 & 20 & 5 & 20 & 20 & 1 & 10 & 10 & 10 & 0.1 & 0.1 & 601.5 & 591.7 & 9.8 \\
12 & 1 & 5 & 20 & 5 & 20 & 10 & 1 & 10 & 10 & 2 & 0.1 & 2041.2 & 2051.1 & -9.9 \\
\hline
\end{tabular}

RN: Run No, EPA: Experimental Protease Activity (U/mL), PPA: Predicted Protease Activity (U/mL)

\section{Results and Discussion}

Optimization of Medium Components by Plackett-

\section{Burman Design}

In the subject of commercial enzyme industry, obtaining inexpensive media components and composing a cost-effective medium formulation is a quite important issue (Chauhan and Gupta, 2004). The present study investigated the effects of 11 different factors (inoculum size and 10 different media components) on protease activity by running 12 experiments between low (-1) and high (+1) levels via Plackett-Burman Design. Experimental design matrix with the results (protease activity) is shown in Table 2. As can be seen from the table, selected media components significantly affected the protease activity which varied from 41 to $2280 \mathrm{U} / \mathrm{mL}$. The highest activity was obtained in run 8 that was followed by the runs 10, 7, 6, 12 and 5. The conditions where higher protease activities were detected contained yeast extract at maximum level. This inferred that the yeast extract is an important factor for the protease production by Bacillus sp. EBTA6. On the other hand, the lowest activity $(41.5 \mathrm{U} / \mathrm{mL})$ was detected in run 1 in which all the nitrogen sources were at the minimum level $(1 \mathrm{~g} / \mathrm{L})$ that demonstrated the significance of nitrogen on the protease production. 
Table 3. Effects and contributions of various factors using ANOVA

\begin{tabular}{|c|c|c|c|c|c|c|c|}
\hline Parameters & Effect & $S S$ & $\mathrm{df}$ & $M S$ & F-Value & P-Value & $\mathrm{C} \%$ \\
\hline Inoculum size & -40.35 & 4885.71 & 1 & 4885.71 & - & - & 0.05 \\
\hline Glucose & -62.91 & 11873.42 & 1 & 11873.42 & - & - & 0.13 \\
\hline Sucrose & 52.97 & 8419.93 & 1 & 8419.93 & - & - & 0.09 \\
\hline Fructose & 60.36 & 10932.4 & 1 & 10932.4 & - & - & 0.12 \\
\hline Starch & 62.31 & 11648.02 & 1 & 11648.02 & - & - & 0.13 \\
\hline Yeast extract & 1641.2 & 8081000 & 1 & 8081000 & - & - & 93.78 \\
\hline Casein & 237.31 & 168900 & 1 & 168900 & - & - & 1.96 \\
\hline Peptone & 194.53 & 113500 & 1 & 113500 & - & - & 1.31 \\
\hline Ammonium sulphate & 68.92 & 14250.82 & 1 & 14250.82 & - & - & 0.16 \\
\hline Magnesium sulphate & -19.74 & 1169.53 & 1 & 1169.53 & - & - & 0.01 \\
\hline Dipotassium phosphate & 251.31 & 189500 & 1 & 189500 & - & - & 2.19 \\
\hline Pure Error & & 0 & 0 & & & & \\
\hline Cor Total & & 8616000 & 11 & & & & \\
\hline
\end{tabular}

SS: Sum of Square, MS: Mean Square, C \%: Contribution \%

Table 4. Effects of various parameters using transformed ANOVA

\begin{tabular}{|c|c|c|c|c|c|c|}
\hline Parameters & Sum of Squares & df & Mean Square & F-Value & P-Value & \\
\hline Model & 8553000000 & 4 & 2138000000 & 236.89 & $<0.0001$ & Significant \\
\hline Yeast extract & 8081000000 & 1 & 8081000000 & 895.29 & $<0.0001$ & \\
\hline Casein & 168900000 & 1 & 168900000 & 18.72 & 0.0035 & \\
\hline Peptone & 113500000 & 1 & 113500000 & 12.58 & 0.0094 & \\
\hline Dipotassium phosphate & 189500000 & 1 & 189500000 & 20.99 & 0.0025 & \\
\hline Residual & 63180 & 7 & 9026 & & & \\
\hline Cor Total & 8616000000 & 11 & & & & \\
\hline
\end{tabular}

Table 5. Solution values on optimization of the protease activity

\begin{tabular}{cccc|ccc}
\hline & \multicolumn{3}{c|}{ Variables } & \multicolumn{3}{c}{ Response (Protease activity) } \\
\hline $\begin{array}{c}\text { Yeast extract } \\
(\mathrm{g} / \mathrm{L})\end{array}$ & $\begin{array}{c}\text { Casein } \\
(\mathrm{g} / \mathrm{L})\end{array}$ & $\begin{array}{c}\text { Peptone } \\
(\mathrm{g} / \mathrm{L})\end{array}$ & $\begin{array}{c}\text { Dipotassium } \\
\text { phosphate }(\mathrm{g} / \mathrm{L})\end{array}$ & $\begin{array}{c}\text { Actual value } \\
(\mathrm{U} / \mathrm{mL})\end{array}$ & $\begin{array}{c}\text { Predicted value } \\
(\mathrm{U} / \mathrm{mL})\end{array}$ & $\begin{array}{c}\text { Difference } \\
(\%)\end{array}$ \\
\hline 9.98 & 8.69 & 9.89 & 1.27 & 2411.42 & 2286.44 & 5.46 \\
\hline
\end{tabular}

In order to observe the effect of each variable on the protease activity, the results were analyzed statistically by ANOVA $(\mathrm{P}<0.05)$ and the most efficient factor was determined as yeast extract with a contribution ratio of $93.78 \%$ (Table 3 ). The other factors effecting the enzyme production were dipotassium phosphate $(2.19 \%)$, casein $(1.96 \%)$, and peptone $(1.31 \%)$ while the rest of the factors were below $1 \%$ contribution ratio (Table 3 ). In general, organic nitrogen sources have positive effect on protease secretion, because other than nitrogen they also contain carbon, minerals and ions which enhance the enzyme biosynthesis (Shabbiri et al., 2012). In this study, all the organic nitrogen sources improved the protease production. However, the effects of casein and peptone were substantially low compared with the effect of yeast extract. Bacillus sp. NPST-AK15 (Ibrahim et al., 2015) had also produced the highest amount of protease with yeast extract as the nitrogen source that is in agreement with the current study. On the other hand, effect of ammonium sulfate on the protease production was insignificant $(0.16 \%$ contribution).

Glucose, fructose, sucrose and starch were tested as carbon sources and it has been observed that they do not have significant effects on the protease production. This has probably stemmed from the catabolite repression mechanism in which peptides and amino acids can be supplied as both carbon and nitrogen sources. In addition, the cells could have high energy status in the presence of sugars that causes the repression of protease synthesis. It was reported that the catabolite control protein (CcpA) which regulates mechanisms of glucose catabolism may also behave as a repression signal in protease synthesis (Sharma et al., 2017). Among oligo elements, dipotassium phosphate $(1.270 \mathrm{~g} / \mathrm{L})$ had the most intense influence on the protease production. This finding is in agreement with Hammami et al. (2018) who found that $0.5 \mathrm{~g} / \mathrm{L}$ of dipotassium phosphate had the greatest effect on the production of alkaline proteases by Bacillus mojavensis.

Half-normal probability plot (Figure 1) shows that eight of the eleven tested parameters had a positive effect on protease yield while three variables had a negative effect which were inoculum size, glucose, and magnesium sulfate. Calculations were also presented as half-normal probability plot of the effects which represents the normally distributed effects (Figure 1) (Ghosh and Mukherji, 2018). The factors that lie along the line are negligible and the rest of the factors that are not on the line represent significant factors (Sudar et al., 2013). Thus, yeast extract, dipotassium phosphate, casein, and peptone are determined as significant factors on the protease production.

For further confirmation of the results, an ANOVA was applied to the selected factors to differentiate them as significant and insignificant. P-values less than 0.05 indicate that the model terms are significant, and the values greater than 0.05 indicate that the model terms are insignificant 
(Sudar et al., 2013). To obtain P and F-values, the least significant factors including inoculum size, glucose, sucrose, fructose, starch, ammonium sulfate, and magnesium sulfate were ignored which were determined based on half-normal probability plot. Because they were selected as error terms and cannot be included in the model. The transformed ANOVA data is shown in Table 4. $\mathrm{P}$ values less than 0.05 indicate significant model terms and in this case, all the four selected model terms are significant. While yeast extract is the most significant valuable $(\mathrm{P}<0.001)$, dipotassium phosphate, casein, and peptone follows it up, respectively. The model F-value of 236.89 implies the model is significant. The predicted $\mathrm{R}^{2}$ of 0.9784 is in reasonable agreement with the adjusted $\mathrm{R}^{2}$ of 0.9885 ; i.e. the difference was less than 0.2. The deduced equation for the protease production by Bacillus sp. EBTA6 regarding the model is as follows:

$$
\mathrm{EA}=\mathrm{A}+(\mathrm{B} \times \mathrm{YE})+(\mathrm{D} \times \mathrm{C})+(\mathrm{E} \times \mathrm{P})+(\mathrm{F} \times \mathrm{DP})(3)
$$

Where, the units of the factors are as $\mathrm{g} / \mathrm{L}$.

$$
\begin{aligned}
\mathrm{EA} & =\text { Enzyme activity }(\mathrm{U} / \mathrm{mL}) \\
\mathrm{A} & =-141.78184 \\
\mathrm{~B} & =182.35556 \\
\mathrm{D} & =26.36790 \\
\mathrm{E} & =21.61481 \\
\mathrm{~F} & =132.26901 \\
\mathrm{YE} & =\text { Yeast extract } \\
\mathrm{C} & =\text { Casein } \\
\mathrm{P} & =\text { Peptone } \\
\mathrm{DP} & =\text { Dipotassium phosphate }
\end{aligned}
$$

\section{Validation of the Model}

The model equation obtained was validated experimentally by optimizing the most significant parameters. Figure 2 shows Pareto chart of the effects in which the factors above t-value limit are the significant parameters selected to run the solution. The solution obtained which had the maximum protease activity has chosen for validation. The parameters with actual and predicted responses (protease activities) related to selected solution are presented in Table 5. Yeast extract $(9.98 \mathrm{~g} / \mathrm{L})$, casein $(8.69 \mathrm{~g} / \mathrm{L})$, peptone $(9.89 \mathrm{~g} / \mathrm{L})$, and dipotassium phosphate $(1.27 \mathrm{~g} / \mathrm{L})$ were optimum parameters and maximum theoretical (predicted) activity was 2286.44 $\mathrm{U} / \mathrm{mL}$. Actual (experimental) response was measured as $2411.42 \mathrm{U} / \mathrm{mL}$ which was very close to predicted value. Thus, this result validates the model with a coherence with the predicted and actual values.

\section{Conclusion}

Plackett-Burman Design was used to determine 11 selected factors including inoculum size, carbon sources (glucose, fructose, sucrose, starch), nitrogen sources (casein, peptone, yeast extract, ammonium sulfate) and some inorganic substances (dipotassium phosphate, magnesium sulfate) on the secretion of protease by Bacillus sp. EBTA6. Media composition has substantially effected the protease production, especially yeast extract was determined as the most significant factor. Dipotassium phosphate, casein, and peptone had also effected the protease production positively. However, carbon sources, inorganic nitrogen source (ammonium sulfate) and inoculum size did not have any contribution. An equation was developed regarding the significant factors and it fitted well with the experiments. Validation test resulted in 5.5\% difference between the predicted value $(2286.4 \mathrm{U} / \mathrm{mL})$ and experimental value $(2411.4 \mathrm{U} / \mathrm{mL})$.

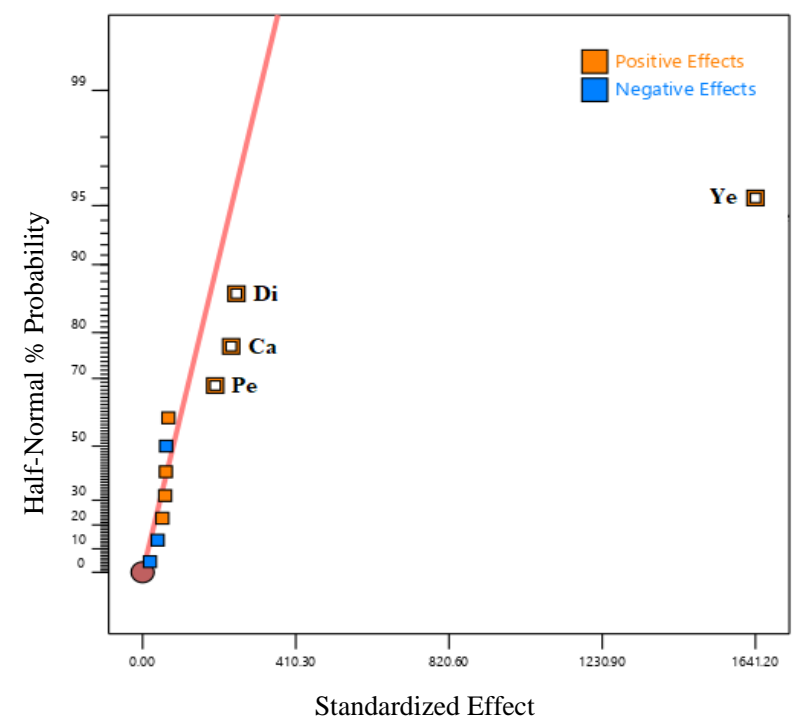

Figure 1. Half-normal probability plot of the factors on the protease production

(Ca: casein, Di: dipotassium phosphate, Pe: peptone, Ye: yeast extract)

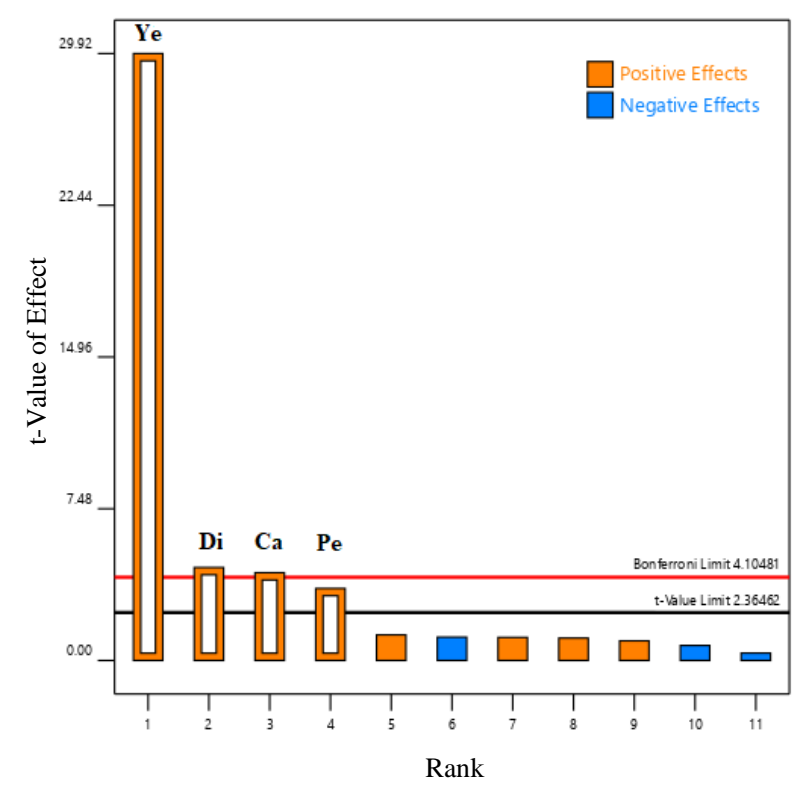

Figure 2. Pareto chart of the effects

(Ca: casein, Di: dipotassium phosphate, Pe: peptone, Ye: yeast extract)

\section{References}

Banik RM, Prakash M. 2004. Laundry detergent compatibility of the alkaline protease from Bacillus cereus. Microbiol. Res., 159: 135-140. DOI: 10.1016/j.micres.2004.01.002

Beg QK, Sahai V, Gupta R. 2003. Statistical media optimization and alkaline protease production from Bacillus mojavensis in a bioreactor. Process Biochem., 39: 203-209. DOI: 10.1016/S0032-9592(03)00064-5 
Białkowska AM, Krysiak J, Florczak T, Szulczewska KM, Wanarska M, Turkiewicz, M. 2018. The psychrotrophic yeast Sporobolomyces roseus LOCK 1119 as a source of a highly active aspartic protease for the in vitro production of antioxidant peptides. Biotechnol. Appl. Biochem., 65: 726738. DOI: $10.1002 /$ bab. 1656

Borhani MS, Etemadifar Z, Emtiazi G, Jorjani E. 2018. A statistical approach for production improvement of a neutral protease from a newly isolated strain of Aeromonas hydrophil. Iran. J. Sci. Technol. Trans. Sci., 42: 1771-1778. DOI: $10.1007 / \mathrm{s} 40995-017-0444-1$

Chauhan B, Gupta R. 2004. Application of statistical experimental design for optimization of alkaline protease production from Bacillus sp. RGR-14. Process Biochem., 39: 2115-2122. DOI: 10.1016/j.procbio.2003.11.002

Ferrero MA, Castro GR, Abate CM, Baigori MD, Sineriz F. 1996. Thermostable alkaline proteases of Bacillus licheniformis MIR 29: isolation, production and characterization. Appl. Microbiol. Biotechnol., 45: 327-332. DOI: $10.1007 / \mathrm{s} 002530050691$

Ghosh P, Mukherji S. 2018. Optimization of media composition for enhancing carbazole degradation by Pseudomonas aeruginosa RS1. J. Environ. Chem. Eng., 6: 2881-2891. DOI: 10.1016/j.jece.2018.04.043

Gupta R, Beg Q, Lorenz P. 2002. Bacterial alkaline proteases: molecular approaches and industrial applications. Appl. Microbiol. Biotechnol., 59: 15-32. DOI: 10.1007/s00253002-0975-y

Hammami A, Bayoudh A, Abdelhedi O, Nasri M. 2018. Low-cost culture medium for the production of proteases by Bacillus mojavensis SA and their potential use for the preparation of antioxidant protein hydrolysate from meat sausage byproducts. Ann. Microbiol., 68: 473-484. DOI: 10.1007/s13213-018-1352-0

Horikoshi, K. (1999). Alkaliphiles: some applications of their products for biotechnology. Microbiol. Mol. Biol. Rev., 63: 735-750.

Ibrahim ASS, Al-Salamah AA, Elbadawi YB, El-Tayeb MA, Ibrahim SSS. 2015. Production of extracellular alkaline protease by new halotolerant alkaliphilic Bacillus sp. NPSTAK15 isolated from hyper saline soda lakes. Electron. J. Biotechnol., 18: 236-243. Available from: https://scielo.conicyt.cl/scielo.php?pid=S0717-

34582015000300015\&script=sci_arttext [20.09.2019]. DOI: 10.1016/j.ejbt.2015.04.001

Joo HS, Kumar CG, Park GC, Kim KT, Paik SR, Chang CS. 2002. Optimization of the production of an extracellular alkaline protease from Bacillus horikoshii. Process Biochem., 38: 155-159. DOI: 10.1016/S0032-9592(02)00061-4

Karlapudi AP, Krupanidhi S, Reddy ER, Indira M, Bobby MdN, Venkateswarulu TC. 2018. Plackett-Burman design for screening of process components and their effects on production of lactase by newly isolated Bacillus sp. VUVD101 strain from Dairy effluent. Beni-Seuf Univ. J. Appl. Sci., 7: 543-546. DOI: 10.1016/j.bjbas.2018.06.006

Kaur K, Sondhi S, Kaur PS. 2017. Statistical optimization of the production of protease from Bacillus sp. MSK-01 in submerged fermentation. J. Commer. Biotechnol., 23: 28-37. DOI: $10.5912 / j \mathrm{cb} 810$

Kembhavi AA, Kulkarni A, Pant A. 1993. Salt-tolerant and thermostable alkaline protease from Bacillus subtilis NCIM No. 64. Appl. Biochem. Biotechol., 38: 83-92. DOI: 10.1007/BF02916414
Lim J, Choi YH, Hurh BS, Lee I. 2019. Strain improvement of Aspergillus sojae for increased L-leucine aminopeptidase and protease production. Food Sci. Biotechnol., 28: 121-128. DOI: $10.1007 / \mathrm{s} 10068-018-0427-9$

Limkar MB, Pawar SV, Rathod VK. 2019. Statistical optimization of xylanase and alkaline protease co-production by Bacillus spp. using Box-Behnken Design under submerged fermentation using wheat bran as a substrate. Biocatal. Agric. Biotechnol., 17: 455-464. DOI: 10.1016/j.bcab.2018.12.008

Moon SH, Parulekar SJ. 1991. A parametric study ot protease production in batch and fed-batch cultures of Bacillus firmus. Biotechnol. Bioeng., 37: 467-483. DOI: 10.1002/bit.260370509

Patil U, Mokashe N, Shaha J, Arthekar S, Jagatap H. 2018. Ultrasound-assisted improvements in biocatalytic activity and production of organic-solvent stable protease from Bacillus circulans MTCC 7942. Ultrason. Sonochem., 40: 201-205. DOI: 10.1016/j.ultsonch.2017.07.012

Puri S, Beg QK, Gupta R. 2002. Optimization of alkaline protease production from Bacillus sp. by response surface methodology. Curr. Microbiol., 44: 286-290. DOI: 10.1007/s00284-001-0006-8

Rao MB, Tanksale AM, Ghatge MS, Deshpande VV, 1998. Molecular and biotechnological aspects of microbial proteases. Microbiol. Mol. Biol. Rev., 62: 597-635.

Rao RR, Vimudha M, Kamini NR, Gowthaman MK, Chandrasekran B, Saravanan P. 2017. Alkaline protease production from Brevibacterium luteolum (MTCC 5982) under solid-state fermentation and its application for sulfidefree unhairing of cowhides. Appl. Biochem. Biotechol., 182: 511-528. DOI: $10.1007 / \mathrm{s} 12010-016-2341-\mathrm{z}$

Rekik H, Jaouadi NZ, Gargouri F, Bejar W, Frikha F, Jmal N, Bejar S, Jaouadi B. 2019. Production, purification and biochemical characterization of a novel detergent-stable serine alkaline protease from Bacillus safensis strain RH12. Int. J. Biol. Macromol., 121: 1227-1239. DOI: 10.1016/j.ijbiomac.2018.10.139

Shabbiri K, Adnan A, Jamil S, Ahmad W, Noor B, Rafique HM. 2012. Medium optimization of protease production by Brevibacterium linens DSM 20158, using statistical approach. Braz. J. Microbiol., 43: 1051-1061. DOI: 10.1590/S1517-83822012000300031

Sharma KM, Kumar R, Panwar S, Kumar A. 2017. Microbial alkaline proteases: Optimization of production parameters and their properties. J. Genet. Eng. Biotechnol., 15: 115-126. DOI: $10.1016 /$ j.jgeb.2017.02.001

Si JB, Jang EJ, Charalampopoulos D, Wee YJ. 2018. Purification and characterization of microbial protease produced extracellularly from Bacillus subtilis FBL-1. Biotechnol. Bioproc. E., 23: 176-182. DOI: 10.1007/s12257-017-0495-3

Sudar M, Valinger D, Findrik Z, Vasić-Rački Đ, Kurtanjek Ž. 2013. Effect of different variables on the efficiency of the Baker's yeast cell disruption process to obtain alcohol dehydrogenase activity. Appl. Biochem. Biotechol., 169: 1039-1055. DOI: 10.1007/s12010-012-0056-3

Tari C, Genckal H, Tokatli F. 2006. Optimization of a growth medium using a statistical approach for the production of an alkaline protease from a newly isolated Bacillus sp. L21. Process Biochem., 41: 659-665. DOI: 10.1016/j.procbio. 2005.08.012 